\title{
Correlation between Increased Serum Vascular Endothelial Growth Factor Levels and 30-Day-Outcome After Acute Myocardial Infarction
}

\author{
Sylvia Youvella ${ }^{1}$, Adi Koesoema Aman ${ }^{1}$, Nizam Akbar $^{2}$ \\ ${ }^{1}$ Department of Clinical Pathology, Faculty of Medicine, Sumatera Utara University/Adam Malik Hospital, Medan, Indonesia. E-mail: \\ syvie130190@gmail.com \\ ${ }^{2}$ Department of Cardiology and Cardiovascular Medicine, Faculty of Medicine, Sumatera Utara University/Adam Malik Hospital, Medan, \\ Indonesia
}

\begin{abstract}
Vascular Endothelial Growth Factor (VEGF) plays an important role in the process of regeneration and vascular repair. Atherogenesis and angiogenesis contribute to the formation of coronary collateral circulation as an alternative source of blood supply during the repairing process of Acute Myocardial Infarction (AMI). This study aimed to investigate the elevation of VEGF and its correlation to Peripheral Blood Mononuclear Cells (PBMC) and Major Adverse Cardiovascular Events (MACE). Serum VEGF measurements were carried out on $1^{\text {st }}, 2^{\text {nd }}$, and the $5^{\text {th }}$-day onset of angina on 20 patients using Chemwell Analyzer based on ELISA method. PBMC was counted on days $1^{\text {st }}$ and $5^{\text {th }}$ according to CBC results from Automatic Cell Counter Sysmex XN-1000i. The major adverse cardiovascular event was recorded 30 days after AMI onset. It was found that serum VEGF level in this study was $169.3 \pm 34.5 \mathrm{pg} / \mathrm{mL}$ on the $1 \mathrm{st}$ day, $217.0 \pm 49.7 \mathrm{pg} / \mathrm{mL}$ on the $2^{\text {nd }}$ day, and $249.2 \pm 48.5 \mathrm{pg} / \mathrm{mL}$ on the $5^{\text {th }}$ day. Serum VEGF levels increased gradually and the highest value was found on the $5^{\text {th }}$ day $(p=0.000)$. There was no correlation between elevated serum VEGF levels with PBMC on the $1^{\text {st }}$ day $(p=0.429, r=-0.035)$ and the $5^{\text {th }}$ day of AMI ( $\left.p=0.225, r=+0.081\right)$. There was no correlation between elevated serum VEGF levels with incidence of MACE on 30 days after onset of AMI (OR=0.959, 95\% CI, $p=0.302)$. Serum VEGF concentrations are increased in Acute Myocardial Infarction and can be used as a marker of myocardial injury. However, this study was unable to prove its role in the outcome of AMI.
\end{abstract}

Keywords: Vascular endothelial growth factor, acute myocardial infarction, peripheral blood mononuclear cells, major adverse cardiovascular event

\section{INTRODUCTION}

Acute Myocardial Infarction (AMI) is a condition in which evidence of cardiomyocyte necrosis in a clinical setting consistent with acute myocardial ischemia. ${ }^{1,2} \mathrm{AMI}$ is a fatal disease and still has become a health issue in developed as well as developing countries. According to World Health Organization (WHO), cardiovascular disease is the most common cause of death worldwide, including Indonesia. ${ }^{3}$ Acute myocardial infarction is the second leading cause of death after stroke and its prevalence has reached $1.7 \%$ in Indonesia. ${ }^{4,5}$

In the repair process, the formation of coronary collateral circulation is very important as an alternative source of blood supply that can suppress myocardial ischemia thereby preventing necrosis and triggering the left ventricular remodeling. ${ }^{6}$ Angiogenesis is a vital compensatory mechanism in myocardial ischemia, which supplies the ischaemic tissue with blood. ${ }^{7}$ Angiogenesis is the process of formation of new blood vessels from preexisting vessels, involving cell proliferation, migration, differentiation, tube formation, and regulation of angiogenic factors. It is responsible for a great variety of physiological and pathological processes, including myocardial infarction. ${ }^{8}$ Vascular endothelial growth factor (VEGF) is the key and strongest angiogenic factor to induce angiogenesis. ${ }^{9,10}$ VEGF is a homodimeric glycoprotein, which is the main regulator of the angiogenesis process, which can increase vascular permeability, accelerate the formation of collateral pathways in the myocardium, and trigger tissue repair. ${ }^{11}$

VEGF is produced by endothelial cells, smooth muscle cells, macrophages, cardiac fibroblast, lymphocytes, polymorphonuclear cells, megakaryocytes, monocytes, and platelets. ${ }^{12}$ It is already known that monocytes and lymphocytes can release high amounts of VEGF in a variety of clinical conditions. ${ }^{13}$ Peripheral Blood mononuclear cells 
(PBMCs) consists of lymphocytes ( $T, B$, and natural killer cells), monocytes, and dendritic cells. It is noted that PBMC count increases in the myocardium with necrosis after the onset of AMI. ${ }^{14}$ PBMC is probably one of the candidates, which play a role in improving VEGF circulation in patients with AMI.

The vascular endothelial growth factor is crucially involved in the repair process of vascular endothelial function and vascular regeneration. ${ }^{6}$ Vascular endothelial growth factor is a signal protein, which can increase vascular permeability, stimulate the expression of vascular endothelial cells and induce angiogenesis. ${ }^{15,16}$ Vascular endothelial growth factor secretion is stimulated by hypoxia and ischemia condition in patient with $\mathrm{AMI}^{6,15}$ Study conducted in China found high levels of VEGF on the $7^{\text {th }}$ day after the onset of AMI. It is also found that patients with high VEGF levels have lower MACE incidence than those with low VEGF levels, suggesting a low VEGF level as an independent risk factor against MACE. ${ }^{12}$

The role of VEGF in the progress of AMI disease remains to be proven. No laboratory parameter can assess the occurrence of hypoxia in AMI. The purpose of this research was to determine the increase in serum VEGF levels in AMI patients in Adam Malik Hospital and its correlation with disease outcomes.

\section{METHODS}

The research was conducted from January-March 2019 with a cohort research design. Subjects in this study consisted of AMI patients who attended the IGD Department of Cardiology and Vascular medicine, Adam Malik Hospital, Medan. Complete blood count and serum VEGF levels were tested in all subjects. Acute myocardial infarction was diagnosed based on the criteria of PERKI 2018 as follows: a typical angina complaint increased cardiac marker (Troponin I and CKMB) and EKG showing an ischemia sign.

Laboratory tests were carried out in the Clinical Pathology laboratory, Adam Malik Hospital. Tests on serum VEGF levels were carried out using the Chemwell Analyzer ELISA method and the reagent of Human Vascular Endothelial Growth Factor (VEGF) ELISA Kit-Qayeebio. Peripheral blood mononuclear cells were measured based on the $C B C$ test results using the Automatic Cell Counter Sysmex XN-1000i instrument. The outcome was assessed based on the detection of MACE 30 days after the onset of AMI.

Statistical analysis was conducted using SPSS ver. 25.0. The difference between categorical variables was analyzed using the Wilcoxon test and Friedman test whereas the strength of the correlation between variables was determined using linear regression tests. The logistic regression test was conducted to analyze the increased relationship of VEGF serum by the occurrence of MACE. Analysis was conducted at a $95 \%$ confidence interval and a $p$-value $<0.05$ was considered statistically significant.

This study has received approval from the Health Research Ethics Committee of the Faculty of Medicine, Sumatera Utara University/Adam Malik Hospital, Medan with number No: 105/TGL/KEPK FK USU-RSUP HAM/2019.

\section{RESULTS AND DISCUSSIONS}

Table 1 describes the clinical characteristics of 20 subjects diagnosed with AMI. The mean age of research subjects was $41-78$ years $(58.8 \pm 9.8)$.

Table 1. General characteristics of the study population

\begin{tabular}{lc}
\multicolumn{1}{c}{ Characteristic } & $\begin{array}{c}\text { Value (\%) or Mean } \pm \text { SD } \\
(\mathbf{n = 2 0})\end{array}$ \\
\hline Gender & \\
Male & $16(80)$ \\
Female & $4(20)$ \\
Age (years) & $59.2 \pm 9.7$ \\
Risk factors & \\
Obesity (BMI $\geq 25)$ & $14(70)$ \\
Smoking & $13(65)$ \\
Hypertension (BP $\geq 160$ and/or $95 \mathrm{mmHg})$ & $6(30)$ \\
Diabetes (Random Blood Glucose $\geq 200 \mathrm{mg} / \mathrm{dL})$ & $8(40)$ \\
Dyslipidemia & $15(75)$ \\
cTnI (ng/mL) & $9.5 \pm 10.5$ \\
CKMB (U/L) & $125.6 \pm 109.5$ \\
\hline
\end{tabular}

CTnI (cardiac Troponin I); CKMB (Creatinine Kinase Myocardial Band); BMI (Body Mass Index); BP (Blood Pressure) 
Subjects consisted of male (80\%) and female (20\%). Of 20 subjects, 14 people had a risk factor for obesity (70\%), 13 smokers (65\%), 15 people with dyslipidemia $(75 \%), 6$ people with hypertension (30\%), and 8 people with diabetes mellitus ( $40 \%)$. The mean value of cardiac markers on the first day of the attack was Troponin I with $9.5 \pm 10.5$ and CKMB with 125.6 \pm 109.5 .

Serum VEGF levels gradually increased and the highest value was found on the $5^{\text {th }}$ day (Fig. 1). Serum VEGF levels in AMI patients were $169.3 \pm 34.5$ on the $1^{\text {st }}$ day, $217.0 \pm 49.7$ on the $2^{\text {nd }}$ day, and $249.2 \pm 48.5$ on the $5^{\text {th }}$ day. Serum VEGF levels were significantly higher on the $2^{\text {nd }}$ day than on the $1^{\text {st }}$ day $(p=0.000)$. Serum VEGF levels on the $5^{\text {th }}$ day were significantly higher than on the $2^{\text {nd }}$ day $(P=0.000)$ and compared to the $1^{\text {st }}$ day $(p=0.000)$ as described in Table 2 .

Table 2. Serum VEGF levels in AMI patients

\begin{tabular}{ccc}
\hline Parameter & Mean \pm SD & p-value \\
\hline VEGF $1^{\text {st }}$ day $(\mathrm{pg} / \mathrm{mL})$ & $169.3 \pm 34.5$ & $0.000^{\text {a }}$ \\
VEGF $2^{\text {nd }}$ day $(\mathrm{pg} / \mathrm{mL})$ & $217.0 \pm 49.7$ & $0.000^{\mathrm{b}}$ \\
VEGF $5^{\text {th }}$ day $(\mathrm{pg} / \mathrm{mL})$ & $249.2 \pm 48.5$ & $0.000^{\mathrm{c}}$ \\
\hline
\end{tabular}

Note: a test between VEGF the $1^{\text {st }}$ and $2^{\text {nd }}$ day, $b$ test between VEGF the $2^{\text {nd }}$ and $5^{\text {th }}$ day, $c$ test between VEGF the $1^{\text {st }}$ and $5^{\text {th }}$ day

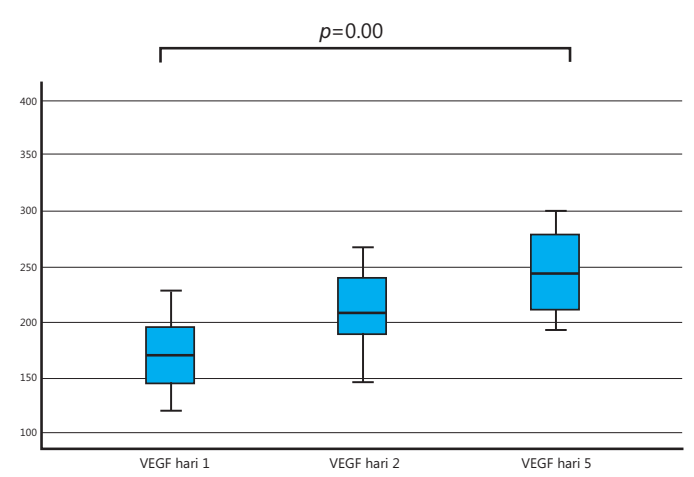

Figure 1. Boxplot Analysis of Serum VEGF Levels on $1^{\text {st }}, 2^{\text {nd }}$, and $5^{\text {th }}$ day
The vascular endothelial growth factor is expressed due to the stimulation of hypoxia during acute myocardial infarction. It has a pro-angiogenetic effect and pro-inflammatory properties to induce vascular permeability. ${ }^{17} \mathrm{~A}$ study conducted by Harada et al. shown that levels of total VEGF-A increased after PCI and reached their peak at day 7 (470.1(309.1-743.7)) pg/mL. ${ }^{18}$ Other studies found that the concentration of serum VEGF was high at 7 days after onset of AMI. ${ }^{19}$ After AMI in mice, new microvessels form in the infarct border zone, the subendocardial space, and the epicardium. Between 2 and 4 days after coronary artery ligation, the capillary network in the border zone starts expanding, with extensive branching and vessel sprouting into the infarct core. ${ }^{16}$ After 7 days, most capillary epithelial cells in the border zone cease to proliferate and some newly formed capillaries enlarge and acquire smooth muscle cell support. ${ }^{16}$ In a classic autopsy series in patients from the pre-reperfusion era, newly formed capillaries penetrated the infarct core from the periphery starting on day 4; ingrowth of blood vessels was most prominent during the second week after AMI, indicating that the process takes longer in patients than in themuch smaller murine heart. ${ }^{16,20}$

Total leukocytes count and differential count in this study showed a higher number of leukocytes, absolute neutrophils, absolute lymphocytes, and PBMC on the $1^{\text {st }}$ day than the $5^{\text {th }}$ day, while the monocytes were higher on the $5^{\text {th }}$ day than the $1^{\text {st }}$ day. According to the results of compare mean analysis, there was no difference of absolute lymphocytes $(p=0.764)$, absolute monocytes $(p=0.489)$, and PBMC $(p=0.852)$ between the first and fifth days. Contrastingly, there was a difference in leukocyte count $(p=0.010)$ and absolute neutrophils $(p=0.009)$ between the first and fifth days (Table 3 ).

Table 3. Difference number of leukocytes and differential count of leukocytes between the first and fifth day of onset in patients with AMI

\begin{tabular}{lccc}
\hline \multicolumn{1}{c}{ Parameter } & Value on $\mathbf{1}^{\text {st }}$ Day & Value on $\mathbf{5}^{\text {th }}$ Day & p-value \\
\hline Leukocyte $(/ \mu \mathrm{L})$ & $14,829 \pm 5,265$ & $11,277 \pm 4,053$ & 0.010 \\
Absolute neutrophil $(/ \mu \mathrm{L})$ & $11,979 \pm 5,340$ & $8,294 \pm 4,367$ & 0.009 \\
Absolute lymphocyte $(/ \mu \mathrm{L})$ & $1,788 \pm 937$ & $1,711 \pm 630$ & 0.764 \\
Absolute monocyte $(/ \mu \mathrm{L})$ & $915 \pm 464$ & $991 \pm 356$ & 0.489 \\
PBMC $(/ \mu \mathrm{L})$ & $2,753 \pm 1,202$ & $2,702 \pm 646$ & 0.852 \\
\hline
\end{tabular}

PBMC (Peripheral Blood Mononuclear Cell) obtained from the summation of absolute lymphocytes with absolute monocytes 
To assess the correlation and strength of the correlation between the number of PBMC with increased levels of serum VEGF on the first and fifth day, linear regression analysis was used (Fig.2; Fig.3). This study found no correlation between the number of PBMC with increased serum VEGF levels on both the first day $(p=0.429, r=-0035)$ and the fifth day $(p=0.225, r=+0.081)$.

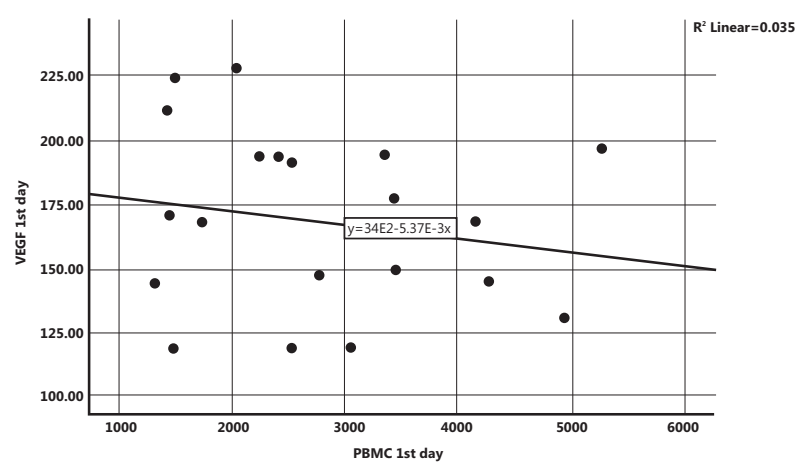

Figure 2. Correlation between number of PBMC and increased Serum VEGF levels on the first day of AMI

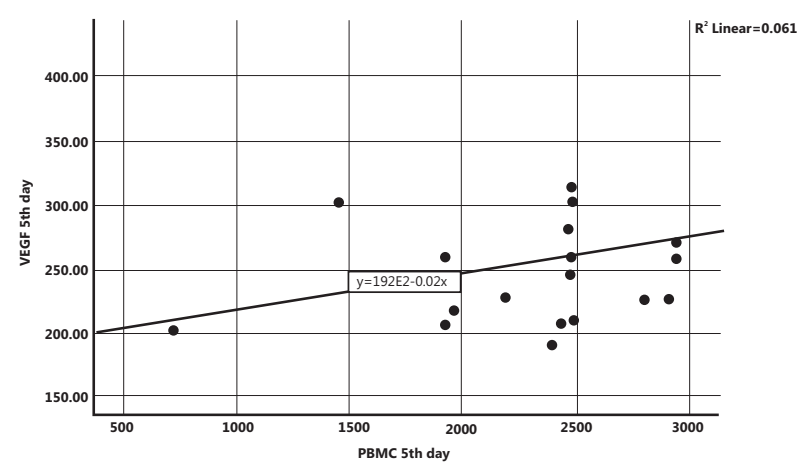

Figure 3. Correlation between number of PBMC and increased Serum VEGF levels on the fifth day of AMI

After MI in mice or rats, ECs in the infarct region express VEGFR2 for at least 7 days. ${ }^{20,21}$ At the same time, monocytes and macrophages, fibroblasts, cardiomyocytes, and epicardium-derived cells produce VEGFA in the infarct region. ${ }^{22}$ Inflammatory cell-derived VEGFA plays a crucial role specifically after injury. ${ }^{23}$ In patients with acute MI, ECs in the infarct region have been shown to express VEGFA and VEGFA plasma levels are elevated. ${ }^{6}$ VEGF can be released by various cell types, and its signals are mediated through the tyrosine kinase receptors, VEGFR-1 (or Flt-1) and VEGFR-2 (or KDR), which are expressed by endothelial cells, monocytes, and many malignant tumors. ${ }^{24}$ Analysis of VEGFRs on PBMCs showed that monocytes expressed detectable but low amounts of VEGFR-1 and VEGFR-3 and no
VEGFR-2. ${ }^{13}$ Serum VEGF levels are linked to thrombocyte counts, probably because platelets release VEGF during blood coagulation. Without consideration of these factors, measurement of VEGF might not reflect the actual situation. ${ }^{13}$

A linear regression test was also used to determine the correlation and strength of the correlation between increased CKMB at the beginning of the disease with the serum VEGF levels. Figure 4 shows that there was no correlation between increased $C K M B$ level and increased serum VEGF levels $(p=0.424, r=-0036)$.

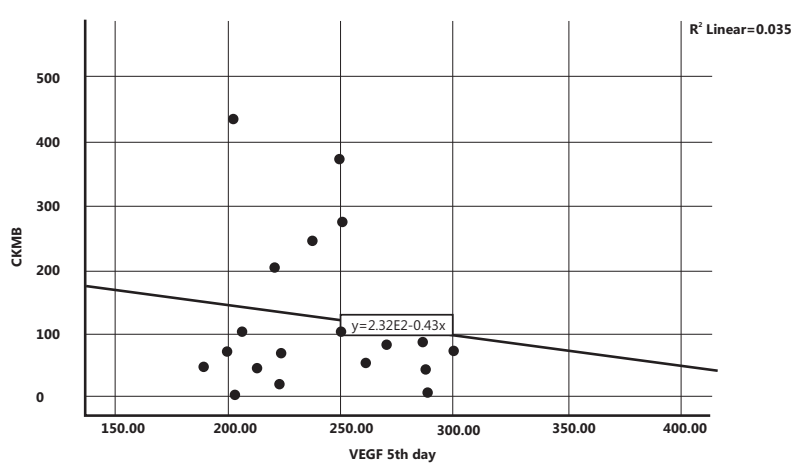

Figure 4. Correlation between increased $C K M B$ and serum VEGF levels in patients with AMI

The same test was also used to assess the correlation and strength of the correlation between increased levels of Troponin I at the beginning of the disease and the serum VEGF levels. It was shown that there was no correlation between both parameters $(p=0.916, r=+0.001)$ as described in Figure 5.

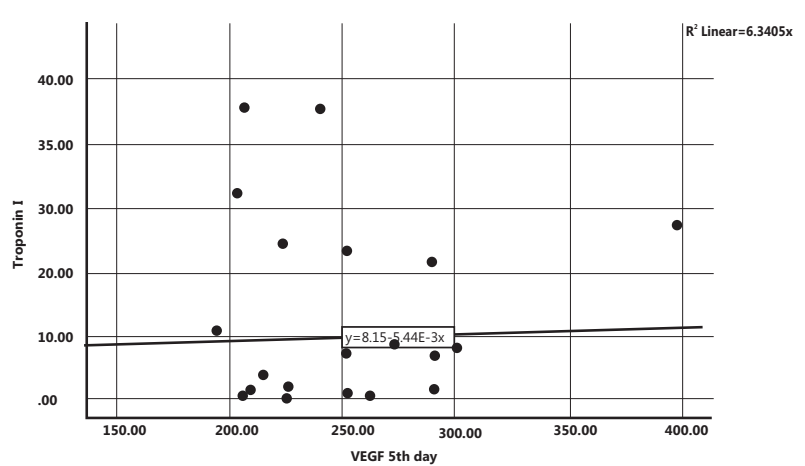

Figure 5. Correlation between increased Troponin I and serum VEGF levels in AMI

Infarct size is major prognostic relevance in patients suffering from AMI. ${ }^{25}$ Study conducted by Tiller et al. reported that Troponin and Creatine Kinase (CK) is myocardial injury biomarkers that reflect infarct size $(p<0.001) .{ }^{26}$ Previous study, 
compare the diagnostic performance of these markers with VEGF in estimating infarct size using ROC curve. This study revealed that the area under the ROC curve (AUC) of VEGF used to predict CAD was 0.667 (sensitivity: 68.5\%; specificity: 60.1\%), which was remarkably powerful compared to CK-MB with an AUC of 0.622 (sensitivity: $60.7 \%$ and specificity: $54.4 \%)^{27}$

All patients who participated in this study followed by 30 days after the onset of angina attack to assess the outcome. The outcome was assessed by observing MACE in each patient. The major adverse cardiovascular event, which occurs 30 days after the onset of the AMI attack was experienced by 12 people (60\%) and 8 people (40\%) who were still alive and had not shown demonstrated complications. The emerging MACE was 6 people (30\%) as a result of death and 6 people (30\%) due to heart failure (Table 4).

Table 4. Frequency of MACE 30 days after AMI

\begin{tabular}{lc}
\hline \multicolumn{1}{c}{ MACE } & Frequency, $\mathbf{n ( \% )}$ \\
\hline Live with no outcome & $8(40)$ \\
Death & $6(30)$ \\
Heart failure & $6(30)$ \\
Total & $20(100)$ \\
\hline
\end{tabular}

To determine the role of increased serum VEGF levels in the AMI outcome, the logistics regression analysis was conducted at the peak serum VEGF with MACE 30 days after the onset of the AMI. In this research, it was found that increased serum VEGF levels did not affect the occurrence of MACE 30 days after AMI attack. Logistics regression analysis results can be seen in Table 5 .

Table 5. Logistic regression analysis of peak serum VEGF levels against the occurrence of MACE 30 days after AMI attack

\begin{tabular}{lccc}
\hline & \multicolumn{3}{c}{ Multivariate Analysis } \\
\cline { 2 - 4 } Parameter & OR & $\begin{array}{c}95 \% \text { CI } \\
\text { (Lower-Upper) }\end{array}$ & p-value \\
\hline Peak serum & 0.959 & $0.885-1.039$ & 0.302 \\
VEGF $(\mathrm{pg} / \mathrm{mL})$ & & \\
\hline
\end{tabular}

The study by Niu et al. with multinomial logistic regression revealed that reduced VEGF levels $(\beta=1.243 ; 95 \% \quad C I, 1.018-1.326 ; p=0.026)$ were independent risk factors for MACE. They concluded that high plasma VEGF levels on the $7^{\text {th }}$ day after the onset of the AMI facilitated long-term prognosis in patients with AMI, while low plasma VEGF levels were an independent risk factor for MACE incidence. ${ }^{19}$ Other studies assessed the comparisons of concentration VEGF-A at days $1,3,7$, and 30 after PCI in patients with and without MACE. The levels of total VEGF-A tended to be lower in patients with MACE than in those without. ${ }^{18}$

\section{CONCLUSIONS AND SUGGESTIONS}

Serum VEGF levels were increased in patients with AMI. Peripheral blood mononuclear cells do not become a major source of increased levels of VEGF circulating in serum. In addition, the study was unable to prove the increase in VEGF as a good prognosis marker in AMI patients. Further researches are required to determine the role of VEGF with long term outcome and source of serum VEGF in AMI patients.

\section{REFERENCES}

1. Thygesen K, Alpert JS, Jaffe AS, Chaitman BR, Bax JJ, et al. Fourth universal definition of myocardial infarction (2018). Eur Heart J, 2019; 40: 237-269.

2. Roffi M, Patrono C, Collet JP, Mueller C, Valgimigli M, et al. 2015 ESC guidelines for the management of acute coronary syndromes in patients presenting without persistent ST-segment elevation: Task force for the management of acute coronary syndromes in patients presenting without persistent ST-segment elevation of the European Society of Cardiology (ESC). Eur Heart J, 2016; 37: 267-315.

3. WHO. About cardiovascular diseases. 2015 Available from: http://www.who.int/cardiovascular_diseases/ about_cvd/en/.[accessed 18 March, 2018].

4. Kementrian Kesehatan RI. Direktorat Jenderal Penyakit Tidak Menular. Profil penyakit tidak menular tahun 2016. Jakarta, Kementrian Kesehatan RI, 2017; 92.

5. Kementrian Kesehatan RI. Penyakit jantung penyebab kematian terbanyak ke-2 di Indonesia. 2019. Available from: https://www.kemkes.go.id/article/ view/19093000001/penyakit-jantung-penyebab -kematian-terbanyak-ke-2-di-indonesia.html. (accessed 14 June, 2021).

6. Wu X, Reboll MR, Korf-Klingebiel M, Wollert KC. Angiogenesis after acute myocardial infarction. ESC Cardiovascular Research, 2021; 117: 1257-1273.

7. Zou J, Fei Q, Xiao $H$, Wang $H$, Liu $K$, et al. VEGF-A promotes angiogenesis after acute myocardial infarction through increasing ROS production and enhancing ER stress-mediated autophagy. J Cell Physiol, 2019; 234(10): 17690-703.

8. Braile M, Marcella S, Cristinziano L, Galdiero MR, Modestino $\mathrm{L}$, et al. VEGF-A in cardiomyocytes and heart diseases. Int. J. Mol. Sci, 2020; 21(15): 5294.

9. Gui C, Zeng ZY, Chen Q, Luo YW, Li L, Chen LL. 
Neuregulin-1 promotes myocardial angiogenesis in the rat model of diabetic cardiomyopathy.Cell Physiol Biochem, 2018; 46(6): 2325-34.

10. Varricchi G, Lo_redo S, Galdiero MR, Marone G, Cristinziano $L$, et al. Innate effector cells in angiogenesis and lymphangiogenesis. Curr. Opin. Immunol, 2018; 53: 152-160.

11. Abhinand CS, Raju R, Soumya SJ, Arya PS, Sudhakaran PR. VEGF-A/VEGFR2 signaling network in endothelial cells relevant to angiogenesis. J. Cell Commun Signal, 2016; 10: 347-354.

12. Peach CJ, Mignone VW, Arruda MA, Alcobia DC, Hill SJ, et al. Molecular pharmacology of VEGF-A isoforms: Binding and signalling at VEGFR2. Int. J. Mol. Sci, 2018; 19: 1264.

13. Hoeres $T$, Wilhelm $M$, Smetak M, Holzmann $E$, Tanzil $\mathrm{GS}$, et al. Immune cells regulate VEGF signalling via release of VEGF and antagonistic soluble VEGF receptor-1. British Society for Immunology, Clinical and Experimental Immunology, 2017; 192: 54-67.

14. Alfatni A, Riou M, Charles AL, Meyer A, Barnig C, et al. Peripheral blood mononuclear cells and platelets mithocondrial dysfunction, oxidative stress, and circulating mtDNA in cardiovascular diseases. J. Clin. Med, 2020; 9: 311.

15. Simons M, Gordon E, Claesson-Welsh L. Mechanisms and regulation of endothelial VEGF receptor signalling. Nat Rev Mol Cell Biol, 2016; 17: 611-625.

16. Dube KN, Thomas TM, Munshaw S, Rohling M, Riley $P R$, Smart N. Recapitulation of developmental mechanisms to revascularize the ischemic heart. JCI Insight 2017; 2: e96800.

17. Garcia R, Bouleti C, Sirol M, Logeart D, Monnot C, et al. VEGF-A plasma levels are associated with microvascular obstruction in patients with ST-segment elevation myocardial infarction. Int J Cardiol, 2019; 291: 19-24.

18. Harada K, Kikuchi $R$, Ishii $H$, Shibata $Y$, Suzuki $S$, et al. Association between the ratio of anti-angiogenic isoform of VEGF-A to total VEGF-A and adverse clinical outcomes in patients after acute myocardial infarction. Int J Cardiol Heart Vasc, 2018; 19: 3-7.

19. Niu J, Han X, Yin J, Zhang Z, Zhang ZT. Correlation between vascular endothelial growth factor and long-term prognosis in patients with acute myocardial infarction. Experimental and Therapeutic Medicine, 2016; 12(1): 475-479.

20. Kobayashi K, Maeda K, Takefuji M, Kikuchi R, Morishita $Y$, et al. Dynamics of angiogenesis in ischemic areas of the infarcted heart. Sci Rep, 2017; 7: 7156.

21. Kurotsu S, Osakabe R, Isomi M, Tamura F, Sadahiro T, et al. Distinct expression patterns of Flk1 and Flt1 in the coronary vascular system during development and after myocardial infarction. Biochem Biophys Res Commun, 2018; 495: 884-891.

22. Williams AL, Khadka V, Tang M, Avelar A, Schunke KJ, et al. HIF1 mediates a switch in pyruvate kinase isoforms after myocardial infarction. Physiol Genomics, 2018; 50:479-494.

23. Howangyin KY, Zlatanova I, Pinto C, Ngkelo A, Cochain $C$, et al. Myeloid-epithelialreproductive receptor tyrosine kinase and milk fat globule epidermal growth factor 8 coordinately improve remodeling after myocardial infarction via local delivery of vascular endothelial growth factor. Circulation, 2016; 133: 826-839.

24. Ferrara N, Adamis AP. Ten years of anti-vascular endothelial growth factor therapy. Nat Rev Drug Discov, 2016; 15: 385-403.

25. Reinstadler SJ, Thiele H, Eitel I. Risk stratification by cardiac magnetic resonance imaging after ST-elevation myocardial infarction. Curr Opin Cardiol, 2015; 30: $681-9$.

26. Tiller C, Reindl M, Holzknecht M, Klapfer M, Beck A, et al. Biomarker assessment for early infarct size estimation in ST-elevation myocardial infarction. European Journal of Internal Medicine, 2019; 64: 57-62.

27. Huang A, Qi X, Cui Y, Wu Y, Zhou S, et al. Serum VEGF: Diagnostic value of acute coronary syndrome from stable angina pectoris and prognostic value of coronary artery disease. Cardiol Res Pract, 2020; 2020: 6786302. 